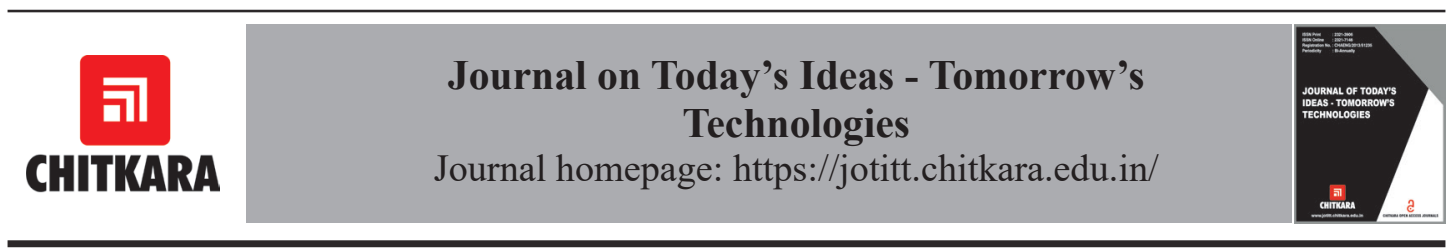

\title{
Covid PDS Plus: An e-PDS \& Healthcare Platform Towards Pandemic Restoration
}

\section{Vedant Shrivastava}

KIIT University, Bhubaneswar, Odisha - 751024, India

Email: vedantshrivastava466@gmail.com

\section{ARTICLE INFORMATION}

Received: June 12, 2020

Revised: June 30, 2020

Accepted: July 03, 2020

Published online: December 03, 2020

Keywords:

Public distribution system, e-PDS,

Covid, Healthcare, Patient triaging

\begin{abstract}
During the COVID-19 crisis, millions of migrants daily-wage workers and homeless people around the world are facing food insecurity. This has forced migrants to travel to their hometowns during the pandemic thereby exposing them to greater health risks and also accelerating the risk of spread of virus. Anecdotal evidence demonstrates the importance of enforcing food security and distribution policies to tide the crisis. However, the effects of these policies on containing mobility during the crisis remain unknown. This paper presents a prototype of technology enabled e-PDS (Pubic Distribution System) and healthcare platform to connect different stakeholders i.e. people, government, NGOs.
\end{abstract}

DOI: $10.15415 /$ jotitt.2020.81003

\section{Introduction}

In a largely unexpected announcement at 8 p.m. on March 24, 2020, Prime Minister Narendra Modi announced that India would go into 21-day lockdown to combat the spread of COVID-19. "Every state, every district, every lane, every village will be under lockdown," said the Prime Minister. Most of India's migrant workers that number more than 100 million and represent over $20 \%$ of the country's workforce, were stranded far from their homes. As many of these migrant workers have minimal savings and limited access to social benefits, their food security suddenly became a critical concern. A large number of migrant workers walked hundreds of miles back to their hometowns following the lockdown announcement [1].
Public Distribution System (PDS) in India was set-up in 1944 to deliver subsidized food to the citizens of the county. Using ration cards, people can purchase food from their local ration shops (that are also known as fair price shops) at subsidized rates. Today in India, there are about 230 million ration card holders and 5,34,000 ration shops, $88 \%$ of which are digitized and possess electronic point of sales (EPoS) machines. During the lockdown, ration card holders could purchase food at cheaper rates and/or receive free food distributed by the government (at least $5 \mathrm{~kg}$ of wheat or rice and $1 \mathrm{~kg}$ of legumes). Despite of the existing food distribution measures, many citizens, especially migrant workers were left without access to these benefits. This is because, historically, ration 
cards could only be used in the card holder's hometown ration shop. In recent years, some states have made ration cards portable, allowing card holders to procure subsidized food at ration shops outside their hometowns as well [2].

In order to overcome the challenges of current public distribution system, this paper has proposed an application/website platform which bridges the gap between the distributors and the customers in this hour of need. It is proposed that the revenue earned from the proposed e-PDS platform will be used for the social welfare for the people in Phase 2 of the project.

\section{Methodology}

The government authorities arranged for distribution of subsidized food to the needy people through various distribution channels, but proper management of these channels remained a challenge. Secondly, most of these migrants who were travelling to their hometowns were spread out all over the places and tracking them remained a challenge. Due to technological barrier there was no means to connect these people to either the NGOs for help or to arrange smooth distribution of supplies for them [3-4].

Our solution is an application platform that connect people in the need for food to the distributors. In order to calculate the subsidies to be given to different people, a machine learning algorithm has been proposed for assessing the economic condition of the people. This application features a portal where citizens can report homeless people and as soon as they are reported, their details are immediately transferred to connected NGOs.

The workflow of the application consists of a User's side and Distributor's side. User side workflow features one-time sign, verification of details and prediction of income index. User is required to order the items or supplies needed one-day in advance through the App and based on his/her income index he will get a subsidy. Once his order is confirmed by a local distributor within 24 hours, he will receive a QR code and using this QR code he can collect the supplies from the local distributor and make the required payment. At the distributor side, one time registration of distributor is done and distribution point in marked. An operator monitors the app and keep track of all the orders that need to be fulfilled by the subsequent day. The App also gives operator access to information like amount of money collected as well as other necessary analysis. Fig. 2 explains in detail the functionality and working of the application on both sides i.e. the user as well as distributor side. It is planned that using this App, poor people with weak economic conditions as well as homeless people reported by the responsible citizens of the country through the App will be served [5-6].

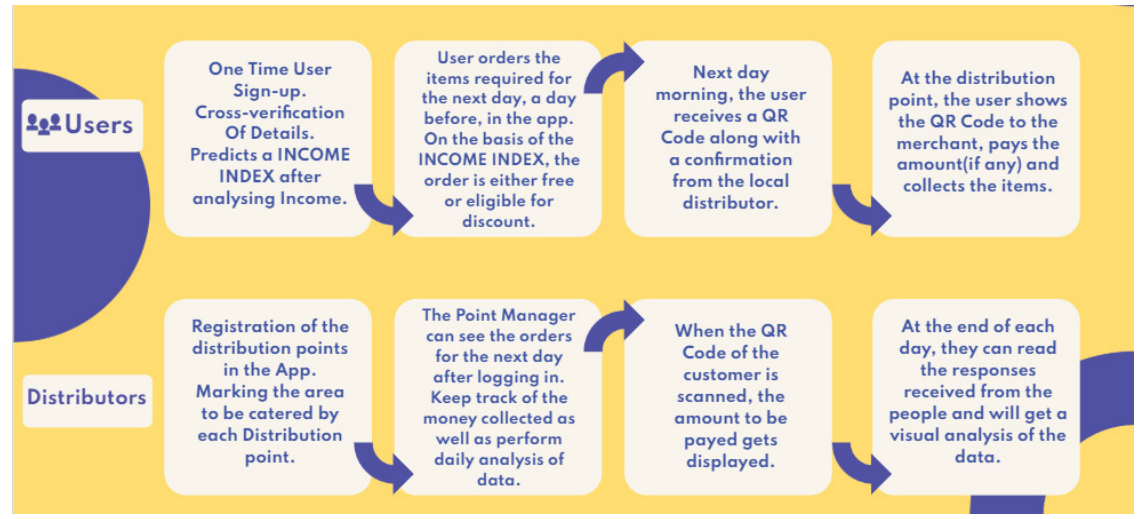

Figure 1: Application workflow 


\subsection{Technology Stacks, Tools Used and Technical Description}

A MERN stack web application using NGINX as reverse proxy and load balancer as shown in Fig. 2 will be used as a website architecture. Complete user interface of the mobile application will be developed using Adobe XD. Fig. 3 showcases the user interface of prototype Android App. Containerizing the application is done using Docker for safe and secure deployment on cloud engines and OpenCV and Pytorch library packages have been used for the programming.

The container deployment of the website and system based automation i.e. CI/CD have been implemented with the use of Docker/Kubernetes for container and Jenkins respectively. Fig. 4 represents the integration of the ML models with the web architecture. The classification model is based on the various factors that impact income of the individuals and these factors ranges from occupation, education level, to age, gender etc [7]. Several classifiers have been proposed for segregating people based on various parameters so that the like groups can be formed. If there is a requirement of providing shelters to the people registered on this web application then the proposed model does all the calculations regarding the cost of sheltering, area required etc [8]. Deep learning and computer vision concepts are used for the purpose of verification. These

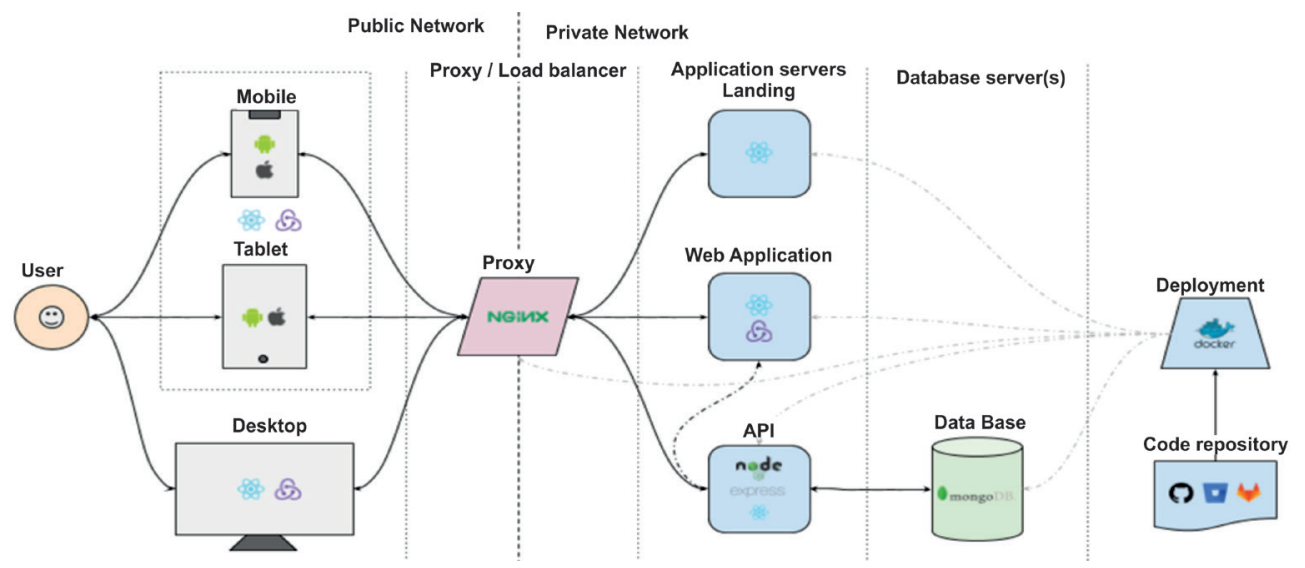

Figure 2: The web architecture

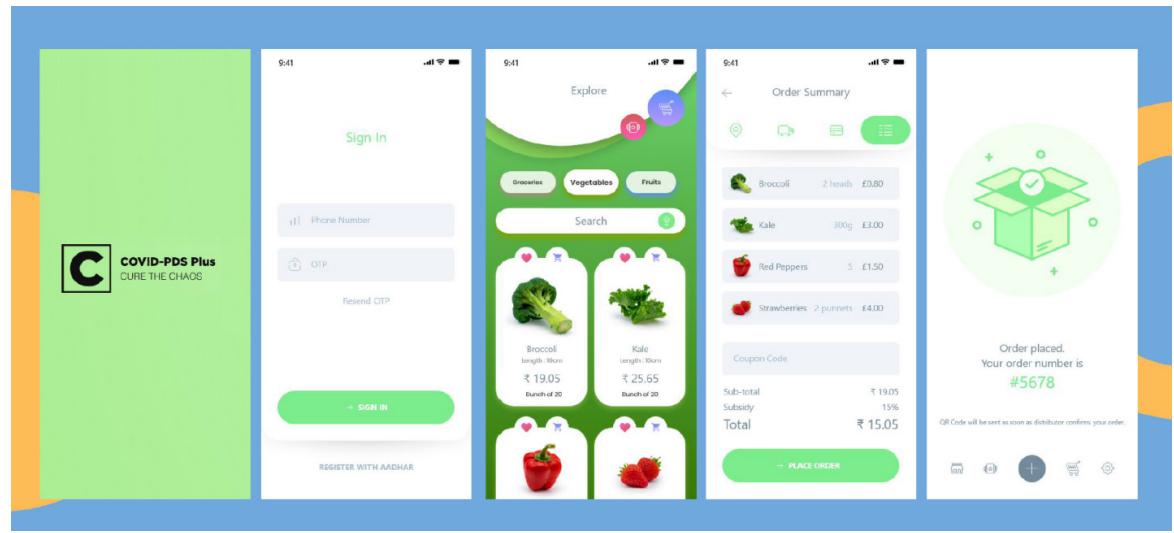

Figure 3: Android App UI 
deep learning models can also be used for educating people about subjects like handwashing, hygiene, cleanliness etc [9]. Pytorch/ TensorflowKeras deep learning libraries have been used to enhance the performance of the models using gradient descent and backpropagation. Deep neural network models have been incorporated to prevent any wrongful entry of data on part of the users while registration and generative adversarial network model has been used for age determination.

\section{Results and Discussion}

Enforcing lockdown in a country of India's scale is socially, economically, institutionally, and politically very demanding and disproportionately affects poor, daily wage earners, and other marginalized groups [10-14]. This indicates that inadequate and uneven safety net may leave many from these economically vulnerable groups without access to food and other key services [15-17]. However, it should be noted that compare to other countries with similar income level, India's social safety net is quite extensive. An elaborate array of programs exists to assist poor, including the world's largest food-based social program, the Public Distribution System (PDS), covering
800 million people. To respond quickly, India is utilizing these existing schemes and reshaping them to address the unique challenges from COVID-19 [18]. On March 26, government announced $\$ 22.6$ billion relief package ensuring food security to the millions. PDS played a key role in providing $5 \mathrm{~kg}$ of either rice or wheat and $1 \mathrm{~kg}$ of preferred pulses for free [19-20].

PDS coverage in urban areas is low (about $50 \%)$ thus leaving out many urban poor. In response to the pandemic, government agencies need to quickly expand the list of eligible households. If necessary, the broader coverage could be rolled back after COVID-19 subsides. So far, only the Delhi government has announced that people without ration cards could also get rations. Bihar announced use of direct cash transfers (DCTs), depositing funds to the bank accounts of ration card holders (RCH). Thus. the outlook of the proposed application makes this challenge quite an easy task to solve [2122]. With commodities prices expected to rise, and only small amounts assigned to pulses in the relief package, ensuring proper diet is challenging and this problem can be solved through e-PDS platform that proposes to offer subsidy based on income index. Fig. 5 shows the home page of the e-PDS website developed by the team.

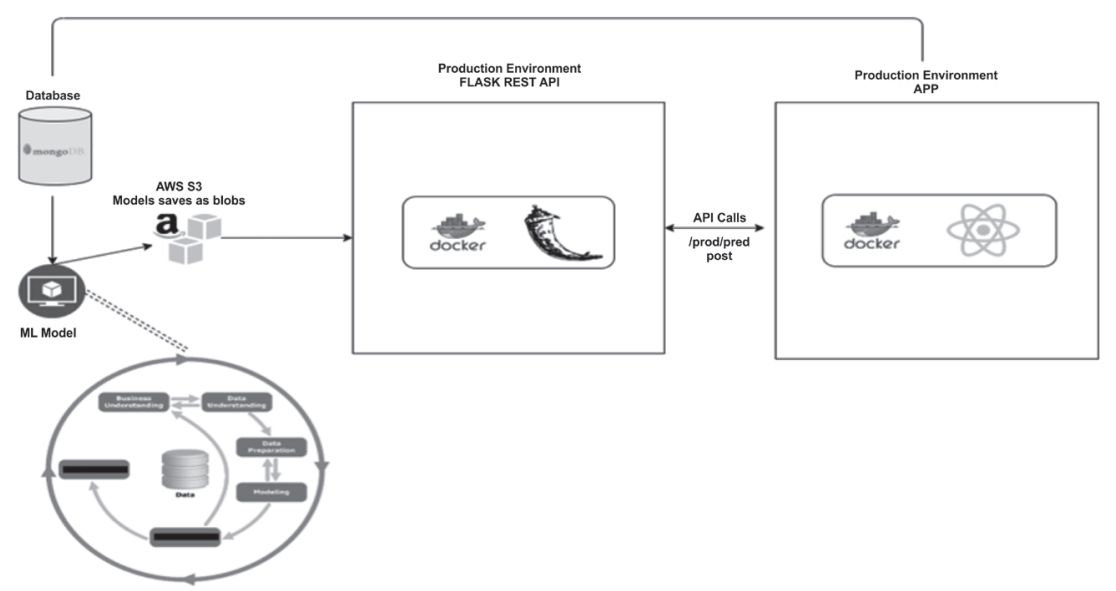

Figure 4: Integrating the ML model with web application 


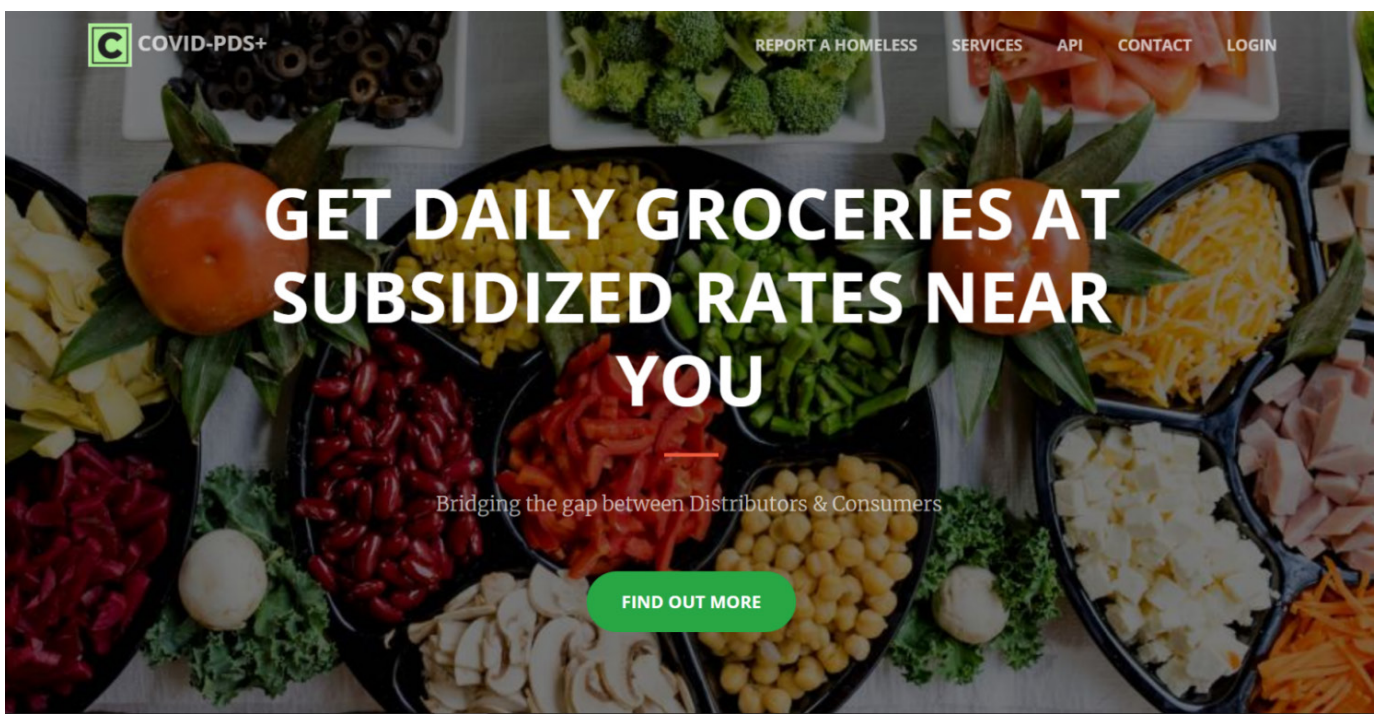

Figure 5: The website

\section{Conclusion}

This work has aimed at providing an easy, effective and complete technology enabled method for the public distribution of food, finding homes for the homeless, providing at the home care to those affected by the pandemic, as well as monitoring the COVID-19 spread by keeping in mind the concept of social distancing. Our e-PDS platform offers multi-language support to cater to diverse population of the country. Income index calculation through predictive analytics as proposed in this work can also be used in other projects requiring classification according to economic conditions. With the use of real time analytics and QR code checkout, waiting time at the distribution points is lowered and objective of realizing social distancing can be achieved.

\section{References}

[1] Facebook. Facebook Data for Good. 2020. [Online] Available: https://dataforgood.fb.com/ [Accessed: April 2020].

[2] K. Munshi and M. Rosenzweig. Networks and Misallocation: Insurance, Migration, and the Rural-Urban Wage Gap. American Economy Review. vol. 106, pp. 46-98, 2016. https://doi.org/10.1257/aer.20131365

[3] Z. L. Kone, M. Y. Liu, A. Mattoo, C. Ozden and S. Sharma. Internal borders and migration in India. Journal of Economic Geography. vol. 18, no. 4, pp. 729-759, 2018. https://doi.org/10.1093/jeg/lbx045

[4] H. Mander. For India's migrant workers, the prospect of life with dignity has become more remote. Scroll.in (2020). [Online] Available: https://scroll.in/article/961030/harshmander-for-indias-migrant-workers-theprospect-of-life-with-dignity-has-becomemore-remote [Accessed: April 2020].

[5] M. U. G. Kraemer, et al. The effect of human mobility and control measures on the COVID-19 epidemic in China. Science, 368, pp. 493-497, 2020.

https://doi.org/10.1126/science.abb4218

[6] J. S. Jia, et al. Population flow drives spatio-temporal distribution of COVID-19 in China. Nature, 2020.

https://doi.org/10.1038/s41586-020-2284-y

[7] A. Sharma. After Janata Curfere, India gets 
ready for long haul. Economic Times, 2020. [Online] Available: https://economictimes. indiatimes.com/news/politics-and-nation/ after-janata-curfew-india-gets-ready-forlong-haul/articleshow/74765039.cms [Accessed: May 2020].

[8] S. Ghosh, "Ration shops need to follow these rules during lockdown, News 18 Bangla, 2020. [Online] Available: https://bengali.news 18. $\mathrm{com} /$ news/south-bengal/ration-shops-needto-follow-these-rules-during-lock-downss-430678.html [Accessed: May 2020].

[9] V. Gaur. COVID-19: UP distributes foodgrains to 1.95 crore ration card holders; sets up 527 community kitchens. Economic Times , 2020. [Online] Available: https:// economictimes.indiatimes.com/news / politics-and-nation/covid-19-up-distributesfoodgrains-to-1-95-crore-ration-cardholders-sets-up-527-community-kitchens / articleshow $/ 74867725 . \mathrm{cms}$ ? from $=\mathrm{mdr}$ [Accessed: May 2020].

[10] P. Jebaraj. What is ration card portability? The Hindu, 2019. [Online] Available: https:// www.thehindu.com/news/national/what-isration-card-portability/article29363067.ece [Accessed: May 2020].

[11] L. Butterly. Locked Down and Cast Out:Europe's Migrants Navigate the Pandemic. The Nation, 2020. [Online] Available: https://www. thenation.com/article/world/eu-migrationcovid/ [Accessed: May 2020].

[12] Solidarites. COVID-19 - Colombia: Venezuelan Refugees Live Again in Instability. 2020. [Online] Available: https://www.solidarites. org/en/countries/colombia/covid-19-colombiavenezuelan-refugees-live-again-in-instability/ [Accessed: May 2020].

[13] E. Barbiroglio. COVID-19 is expected to be a key driver of acute food insecurity. Forbes, 2020. [Online] https://www.forbes.com/sites/ema nuelabarbiroglio/2020/04/23/covid-19-isexpected-to-be-a-key-driver-of-acute-foodinsecurity/\#12258a8378ef [Accessed: May 2020].
[14] Department of Food \& Public Distribution. One Nation, One Card Annual Report 2019-20. 2020.

[15] P. Jebaraj. Inter-State ration card portability usage very low: Food Minister. The Hindu, 2020. [Online] Available: https://www.thehindu.com/news/national/ inter-state-ration-card-portability-usagevery-low-food-minister/article3 1537575. ece\#: : text=Although\%2060\%20crore $\% 20$ people\%20are,according\%20to\%20Food\%20 Ministry\%20data [Accessed: May 2020].

[16] The Times of India. SC asks Centre to consider adopting "one nation, one ration card"scheme during lockdown", The Times of India, 2020. [Online] Available: https://timesofindia. indiatimes.com/india/sc-asks-centreto-consider-adopting-one-nation-oneration-card-scheme-during-lockdown/ articleshow/75424806.cms [Accessed: May 2020].

[17] J. Gettleman and K. Schultz. Modi Orders 3-Week Total Lockdown for All 1.3 Billion Indians. New York Times, 2020. [Online] Available: https://www.nytimes. $\mathrm{com} / 2020 / 03 / 24 / \mathrm{world} / \mathrm{asia} / \mathrm{india}-$ coronavirus-lockdown.html [Accessed: May 2020].

[18] Ministry of Finance. Economic Survey 20162017. 2017.

[19] J. Slater and N. Masih. In India, the world's biggest lockdown has forced migrants to walk hundreds of miles home. Washington Post, 2020. [Online] Available: https://www. washingtonpost.com/world/asia_pacific/ india-coronavirus-lockdown-migrantworkers/2020/03/27/a62df166-6f7d1 ea-a 156-0048b62cdb51_story.html [Accessed: May 2020].

[20] D. Roy, R. Boss and M. Pradhan. How India's food-based safety net is responding to the COVID-19 lockdown. International Food Policy Research Institute, 2020. 
[21] R. Ali. Telangana: Rs 1,500 ash offer drawes ration card holders to fair price shops. The Times of India. 2020. [Online] Available: https://timesofindia. indiatimes.com/city/hyderabad/telangana-rs1500-cash-offer-draws-ration-card-holders-tofair-price-shops/articleshow/74988708.cms [Accessed: May 2020].

[22] G. Randolph and S. Gandhi. COVID-19 is a wake-up call for India's cities, where radical improvements in sanitation and planning are needed. Washington Post, 2020. [Online] Available:https://www.washingtonpost. com/opinions/2020/04/20/covid-19-iswake-up-call-indias-cities-where-radicalimprovements-sanitation-planning-areneeded/[Accessed: May 2020].

This article has been published as a part of Special regular issue of Journal on Today's Ideas Tomorrow's Technologies. Most of the articles in this issue are the papers for which the original ideas were presented at NOVATE 2020 (https://www.chitkara.edu.in/novate), a competition organized by Chitkara University and supported by Ministry of Electronics and Information Technology, Govt. Of India, Institution's Innovation Council, NSTEDB, Govt. Of India and FICCI. Student participants have written most of these articles. Some basic editing work has been done at the editorial level, but same have not been corrected very rigorously so as to preserve basic touch of student's writing.

\section{旬 \\ CHITKARA}

\section{Journal on Today's Ideas - Tomorrow's Technologies}

Chitkara University, Saraswati Kendra, SCO 160-161, Sector 9-C, Chandigarh, 160009, India

Volume -8, Issue-1

June 2020

ISSN 2321-3906

Copyright: [C 2020 Vedant Shrivastava] This is an Open Access article published in Journal on Today's Ideas

- Tomorrow's Technologies by Chitkara University Publications. It is published with a Creative Commons Attribution- CC-BY 4.0 International License. This license permits unrestricted use, distribution, and reproduction in any medium, provided the original author and source are credited. 